\title{
A educação do educador na sociedade maquínica: a ética e a estética da docência e do desejo de docender
}

Eliana Romãoi

\begin{abstract}
Resumo
Debate a formação de educadores e de professores na sociedade contemporânea, com destaque para as políticas de formação de professores presentes na estrutura institucional do Estado e da sociedade brasileira. Analisa as condições históricas da produção das políticas de educação e, dentro delas, os aspectos de formação e de preparação de professores para as diversas etapas, graus e níveis da Educação Básica. Estuda as causas históricas e políticas do atraso cultural, institucional e político da organização da escola no Brasil e debate as ressonâncias dessas contradições na vida cotidiana, na identidade subjetiva dos professores e em sua autoestima. Apresenta fundamentos filosóficos de uma formação docente para as relações humanas de igualdade e de alteridade, de dialeticidade e de elevação ética e estética. Apresenta a educação escolar como processo de formação humana e destaca a tarefa de educar como processo de desenvolvimento ou de formação humana. Apresenta as esperadas características de uma docência humanizadora e emancipatória. Enuncia processos humanistas e atitudes éticas de acolhimento voltados para as práticas de formação de professores, com destaque para os estágios e os percursos formativos. Destaca com esperanças as novas propostas de novas docências diante de novos sujeitos sociais e de novos desafios para a educação e a escola na sociedade tecnológica.
\end{abstract}

Palavras-chave: Formação de Professores. Docender. Humanização. Políticas de Formação.

\section{Resumen}

Debate la formación de educadores y de profesores en la sociedad contemporánea, con destaque para las políticas de formación de profesores presentes en la estructura institucional del Estado y de la sociedad brasileña. Analiza las condiciones históricas de la producción de las políticas de educación y, dentro de ellas, los aspectos de formación y de preparación de profesores para las diversas etapas, grados y niveles de la Educación Básica. Se estudia las causas históricas y políticas del atraso cultural, institucional y político de la organización de la escuela en Brasil y debate las resonancias de

\footnotetext{
${ }^{1}$ Pedagoga pela UFAL. Mestre e Doutora em Educação pela UNICAMP. Pós-doutora com bolsa CAPES/Exterior - estágio sênior. Professora da Universidade Federal de Sergipe. Grupos de pesquisa: EduC-Me - Educação, Comunicação e Memória-UFS (em marcha) e Sociedade em Rede, Pluralidade Cultural e Conteúdos Digitais - UNEB. Email: elianaromão@uol.com.br
} 
esas contradicciones en la vida cotidiana, en la identidad subjetiva de los profesores y en su autoestima. Presenta fundamentos filosóficos de una formación docente para las relaciones humanas de igualdad y de alteridad, de dialéctica y de elevación ética y estética. Presenta la educación escolar como proceso de formación humana y destaca la tarea de educar como formación humana. Presenta las esperadas características de una docencia humanizadora y emancipatoria. Enuncia procesos humanistas y actitudes éticas de acogida dirigidas a las prácticas de formación de profesores, las etapas y los itinerarios formativos. Destaca con esperanzas las nuevas propuestas de nuevas docencias ante nuevos sujetos sociales y de nuevos desafíos para la educación y la escuela en la sociedad tecnológica.

Palabras-clave: Formación de profesores. Docender. Humanización. Políticas de formación.

\section{Introdução}

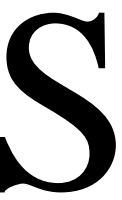
obreleva, hoje, a exaltação da sociedade tecnológica, embora assim tenha sido desde sempre. Isso porque, a cada era, a sociedade exalta um tipo de tecnologia que impacta o rumo e o rosto das relações humanas. Desde a descoberta do fogo, passando pela descoberta da roda, da escrita, do alfabeto, do ouro, até chegar às tecnologias digitais, cada uma trouxe, em maior ou menor escala, algum tipo de rebuliço na vida em sociedade. Em toda era, o homem foi experimentando sua criatividade e encontrando meios de sobrevivência, ampliando as mais diferentes formas de manejar "confortos tecnológicos".

Isso gerou mudanças de hábitos, mudanças de vida, mudanças na ética e na estética das mais variadas formas de relações humanas. Mudanças que também geraram desconfortos e incertezas. Se é certo que a tecnologia não veio para substituir o homem, é certo, igualmente, que diminuiu sua presença em determinados setores - seja na vida do campo, seja na vida urbana. Umberto Eco exemplifica alguns desses rebuliços causados na vida cotidiana em face de uma determinada revolução tecnológica. Para cada passo dado em nome do progresso, diz o escritor, o desemprego foi afetado, a exemplo dos tecelões no século XVIII que chegavam ao ponto de quebrar as máquinas de tecer com medo de ficarem sem trabalho (ECO, 2003). Esse autor se refere ainda nas suas recordações ao conhecido carroceiro da região, o qual era habitualmente chamado para levar a família do autor e as 
bagagens à estação. Na atualidade, ainda há, no país, mais do que se pensa, inúmeras carroças ${ }^{2}$ que servem de táxi para transportar turistas, mas sem a mesma expressividade de tempos passados. Importa, porém, destacar que "o futuro não é um destino determinado pelo desenvolvimento da tecnologia, mas obra do homem" (SCHAFF, 1995, p. 154). Segundo esse mesmo estudioso, no

[...] cenário atual vemos o homo autocreator, o homem criador do seu próprio destino e que esteve presente durante todo desenvolvimento histórico. Ele não pode na verdade configurar de modo arbitrário este destino, tem que agir sob condições determinadas e de acordo com elas, mas, apesar disso, é livre para escolher entre as alternativas que lhe são apresentadas. [...] $\mathrm{O}$ indivíduo humano é o que é por estar vinculado - por valores, estereótipos [...] - à sociedade; também está inseparavelmente vinculado a ela pelo papel que desemplenha na intrincada rede de relações sociais. (SCHAFF, 1995, p. 154)

Nesse contexto, destaca-se a importância da Educação na direção de assegurar a formação cultural, ética e estética das novas gerações. Assim, o professor ocupa o miolo das discussões e seu ofício é cada vez mais requisitado, embora menos (re)conhecido. Sua formação é colocada a toda prova, sua função repensada, sua pedagogia - com cheiro de bolor - pede nova reconfiguração. Proclama-se a necessidade de uma revolução nos cursos de formação de professor, afirma-se: “[...] Uma verdadeira revolução nas estruturas institucionais formativas e nos currículos da formação é necessária [...]. A fragmentação formativa é clara.” (BETTI, 2009, p. 256). As exigências de reformulação se estendem às diferentes modalidades de formação ${ }^{3}$. Para cada nova opção, novas exigências, novos meios, novas docências e novas estéticas. Em educação, sobretudo, o dia de hoje não é tão igual ao dia de ontem, pois que inexiste educabilidade na "rotinice" e na

\footnotetext{
${ }^{2}$ Em Galinhos, no Rio Grande do Norte, carroças são utilizadas para atrair e conduzir os turistas para suas hospedarias, causando, assim, espanto em face dos contrastes de uma realidade influenciada, em grande medida, pelos avanços da tecnologia.

${ }^{3}$ Em particular a Educação a Distância $(\mathrm{EaD})$ que carrega em suas mochilas a tensão de mostrar, no meio de tantas críticas e acusações - mais apressadas que refletidas - que muitos de seus alunos encontraram seu lugar na sociedade em razão, sobretudo, da oportunidade da formação com as peculiaridades que a Ead promove.
} 
"mesmice" com as quais poucos conseguiriam sobreviver na profissão. E, a docência "só é suportável se reinventada a cada dia. Como a vida". (ARROYO, 2000, p.170). Nessas advertências subjazem apelos para uma outra educação do educador. Essa busca incessante não escapa de novas perguntas, entre as quais avulta uma questão principal seguida de questões correlatas: Quem educa o educador que educará crianças e adolescentes deste tempo? O que leva alguém a desejar ser professor(a)? Quais seriam as tarefas das instituições de formação de professores para compreender, encantar e formar novos docentes para novas infâncias e novos sujeitos?

O presente artigo não tem a pretensão de encerrar os estranhamentos contidos nas indagações supracitadas, mas trazê-las para a agenda de discussão em que a educação é a protagonista. Educar é um processo multilateral em que se renova e abarca-se uma permanente atenção e renov(ação) por parte das instituições, de seus professores e seus alunos. É constituído ao longo da vida, a partir de muitos e de diferentes bocadinhos, em cada canto da terra. Diferentes autores estão a afirmar que a educação ultrapassa os limites do muro da escola, embora, "todos os sítios onde se transmite e adquire informação também constituem escolas"”. (ROMANO, 2006, p. 26). Educa-se, em cada minuto da vida, e em “cada rincón de la tierra, [...] a las veces casualmente, de passagem" (SUJOMLINSKI, 1975). E, outras vezes, educa-se sistematicamente ${ }^{5}$ mediante saberes estruturados, intencionalmente definidos, claramente distribuídos por onde o currículo chega a correr, embora pensados para fazer a escola ficar de pé, andar e se fazer um tempo e um espaço de educação. A escola, porém, não é "nem o único, nem o melhor lugar" no qual a educação ocorre.

$\mathrm{Na}$ organização da presente reflexão seleciono alguns pressupostos ao mesmo tempo em que trago o aporte teórico com que tenho dialogado nesses tempos difíceis. Nenhum educador, tenha ele a idade que tiver para muito saber, está adequadamente pronto para educar - sejam crianças, sejam

\footnotetext{
4 “A casa, a escola e o trabalho são espaços de formação e opinião. Mas os meios de informação e de entretenimento, o cinema, a televisão, o rádio, o teatro, os jornais, as revistas sentimentais e outras, os livros, os cartazes também são escolas, num sentido lato." (ROMANO, 2006, p.26)

${ }^{5}$ Cf. Saviani: Sobre a Natureza e especificade da educação, 2003.
} 
adolescentes, sejam jovens, sejam adultos - nem o educador, nem ninguém. Isso não é ruim, nem guarda motivos de queixumes. Ruim é ficar na pura espera, mercê das circunstâncias e, mais que isso, conformado em "seguir sendo como já era".

Ao fazer a confissão abaixo, Guimarães Rosa não apenas proclamou a importância da educação, mas mostrou o que de mais importante ocorre com as pessoas nesse mundo. Mostrou que não é ruim saber-se não terminado, pelo contrário. Disse o escritor: "Oh Senhor... mire e veja: o mais importante e bonito desse mundo é isto: que as pessoas não estão sempre iguais, ainda não foram terminadas - mas que elas vão sempre mudando. Afinam e desafinam. Verdade maior. É o que a vida me ensinou. Isso me alegra, montão.” (ROSA, 2001, p. 39). Quem se julga pronto e, com efeito, sem necessidade de mudança, encontra-se não necessariamente "pronto para morrer", mas pronto para confabular com a morte.

A tarefa de educar não é para qualquer um, nem posta ao acaso. Precisa preparo. Licença para ensinar - Licencia(tura), formação superior, identificação. Mas há pessoas que, uma vez não dando certo em nada na vida, decide ser professor e fazer de uma profissão, de tão elevado grau de exigência, uma escolha secundária, uma ocupação sem importância, um bico. A ética aristotélica, porém, adverte que se pretende cuidar do caráter de alguém, seja quem for que se apresente, não é para qualquer pessoa ao acaso. Se essa pessoa pretende elevar a condição humana, "esta é a pessoa que tem o conhecimento adequado [...] da mesma forma todas as outras profissões cujo exercício pressupõe cuidado e discernimento". (ARISTÓTELES, 2001, p. 204). A essência humana não se faz nem do nada, nem das nuvens, nem do isolamento. Mas de onde vem o germe da essência humana, de vir a ser, de descobrir-se educador? Que espaços, que tempo, que influências e interferências de formação? Que circunstâncias? Para Fernando Pessoa, somos todos escravos das circunstâncias externas. Um dia de sol abre-nos campos largos no meio do cafezal ou até do litoral uma sombra no campo acolhe-nos para dentro [...]; um chegar da noite, alarga [...] a consciência íntima que deve-se repousar (PESSOA, 2016). 
Se é certo, porém, que somos escravos das circunstâncias, não apenas ligadas aos fenômenos da natureza, é certo, igualmente, que tal escravidão não ocorre a ponto de deixar o educador engessado e perplexo, na absoluta ausência do que fazer. Lembre-se que se "somos produtos das circunstâncias, são os homens que as transformam e que o próprio educador precisa ser educado". (MARX \& ENGELS, 1998, p. 100) ${ }^{6}$. Há muito que fazer. O educador tem parte nessas ações tecidas e movidas pela elevação da essência humana. E, o feito não se faz nas sombras, nem nas guerras, nem na amarga solidão.

\section{Feitura do educador se faz "outramente".}

Junta-se a mim. Mas junta-me a ele para servir [...]. (Emmanuel Levinas)

O outro "é meu primeiro ensinamento". Junta-se a mim para (ser)vir. A feitura de si não se faz no isolamento. A feitura do educador, portanto, é resultado do conjunto das relações sociais, faz-se nessas e dessas relações. Não há trabalho mais relacional, e, por isso, de comunicação, que o trabalho docente. E enquanto o realiza, se faz permanentemente sem jamais se concluir. Trata-se de um acontecimento humano que decorre por meio e para além "do encontro das consciências livres, a dos educadores entre si e destes com os educandos”. (PINTO, 2005 p. 48). O que equivale a afirmar que sua feitura se faz em relação genuína. Pois, "onde existe uma relação ela existe para mim". (MARX \& ENGELS, 1998, p. 25). Em relação me faço, sou, me transformo. Sou quem se ajunta ao outro para ser. Ser para além da escola. Ser para além do professor que ensina a lição. Ser em sociedade. Nela promove-se educação no seu sentido mais amplo. Lá educa-se tanto pelo que "se faz, como pelas condições em que se vive". Ela, ainda, "dita seus fins, sua forma, sua extensão, sua qualidade, sua quantidade e a quem e como ela será distribuída". (ORSO, 2011, p. 67). Lá, em sociedade, à

\footnotetext{
${ }^{6}$ Também é dito de outra forma, mas com o mesmo sentido, em Textos sobre Educação e Ensino - "[...] as circunstâncias fazem os homens e o educador, por sua vez, necessita ser educado." (MARX \& ENGELS, 2004, p. 35).
} 
medida que se promove o encontro, criam-se - entre limites, faltas e travas possibilidades humanas. Se é certo, porém, dizer que a educação do educador "é produto das circunstâncias" e se faz sob influência da vida em sociedade, é igualmente certo afirmar que a sociedade não dá conta nem da educação de novas gerações, nem dos profissionais que por esta formação respondem. Isto é, a sociedade não dá conta da educação nas suas especificidades, entre as quais, a educação daquele que educa. É necessário atenção especial com espaços e tempos projetados para a formação de professor sem, todavia, ficar à margem das influências, interferências e interpelações da sociedade. Para Trindade (2012), em uma perspectiva sujeita ao primado da ética, a relação dos sujeitos com os valores e o instituído entram em marcha à medida que aprende-se a construir significados e sentidos sobre a realidade que os envolve de forma consequente, interpelando e sendo interpelados por ela, pelos outros e patrimônio cultural do tempo atual. (TRINDADE, 2012). Importam, sob a ética do sentido e da significação humana, espaços e tempos pensados para o trabalho objetivo de formação e educação genuína - educar para um futuro melhor, a partir da compreensão das lacunas e necessidades do tempo presente. (SUCHODOLSKI, 2002).

Uma educação voltada e produzida a partir da consciência do que falta para evoluir e educar para a cidadania. Educar para a cidadania implica na capacidade de compreender a sociedade na perspectiva de participar da solução de seus problemas (SAVIANI, 2010). Formar para cidadania é formar o ser humano não somente para viver, mas (com)viver em sociedade. Estes apelos incindem na Educação do Educador. E refletem, em grande escala, as prioridades que a política vigente ${ }^{7}$ elege para educação no país. O

\footnotetext{
7 Esta política enseja apoiar “a oferta e a expansão de cursos de formação inicial e continuada a profissionais do magistério pelas instituições públicas da educação. E equalizar nacionalmente as oportunidades de formação inicial e continuada a profissionais do magistério" (GATTI, 2009, p. 52). Mas há de considerar a mentalidade e representações vigentes nas insituições e seus membros, que se acham impregnados pela conformação que se institui entre nós quanto à formação de professores. Acrescente-se que "apenas estimulando a ampliação das estruturas vigentes e seus currículos atuais não se conseguirá realmente transformações em direção a uma nova qualidade para a formação de professores para a educação básica" (BETTI, 2009, p. 53). A relação da autora da mentalidade obsoleta das representações vigentes e a política de formação de professor aproximam-se da relação feita
} 
educador, num permanente aprender de si e consciente de sua imperfeição ${ }^{8}$ segue se fazendo outramente, ajuntando em si fragmentos de uma sociedade inteira. Cada um de "nós" nunca está no singular. Cada um "de nós é dois", é feito de muitos de muitas histórias alheias de "uma sociedade inteira".

Cada um de nós é uma sociedade inteira, um bairro todo de mistério, convém que ao menos tornemos elegante e distinta a vida desse bairro, que nas festas de nossas sensações haja requinte e recato, e porque sóbria a cortesia nos banquetes de nossos pensamentos. (PESSOA, 2006, p. 390)

O outro junta-se a mim para ser nós. O outro, assim, "é mais alto do que eu”. Ser grande e ser nós, com efeito, "não é andar aos encontrões ou empurrar-se em volta de uma tarefa comum". (LEVINAS, 2014, p. 208). Nem sempre, porém, o outro é exaltado na participação da feitura de si e dos feitos que levam seu nome. No poema "Perguntas de um operário letrado", de Bertold Brecht (1998), mostra-se que não há quem se projete sozinho e seja o único merecedor das honrarias que, por vezes, recebe e fica na história - nem reis, nem rainhas, nem príncipes, nem plebeus:

Quem construiu Tebas, a das sete portas?

Nos livros vem o nome dos reis.

Mas foram os reis que transportaram as pedras?

Babilônia, tantas vezes destruída,

Quem outras tantas a reconstruiu? [...]

No dia em que ficou pronta a Muralha da China

Para onde foram seus pedreiros?

A grande Roma está cheia de arcos de triunfo. Quem os ergueu?

Sobre quem triunfaram os Césares? [...]

O jovem Alexandre conquistou as Índias, sozinho?

Cesar venceu os gauleses.

por Aristóteles quando adverte que quando uma pessoa participa ou deseja, graças aos seus cuidados, tornar outras melhores, sejam poucas ou muitas, deve tentar capacitar-se para legislar, na presunção de que podemos tornar-nos melhores graças às leis. (ARISTÓTELES, 2001 p. 205). O notável filósofo grego, de Estagira (384-322 a.C.), parece esquecido no Brasil onde a maioria dos legisladores parecem completamente ignorantes em relação ao papel que lhe é atribuído na legislatura. Pouco tem sido feito pela formação e, entre outros, valorização do professor. Não basta dar apoio à expansão dos cursos de formação. Não basta ampliar as modalidades de formação. Não basta garantir, quando garante, o acesso de todas as crianças à escola. São necessárias instituições com qualidade. Para tanto - e sobretudo - "o professor necessita, por sua vez, ser educado”. (MARX, 2004, p.35)

${ }^{8}$ Para o poeta, alguns querem a perfeição, mas porque não podem tê-la. Seria uma chatice se a tivessem. O perfeito é desumano, porque o humano é imperfeito (PESSOA, 2016). 
Nem sequer tinha um cozinheiro a seu serviço?

Quando sua armada se afundou Filipe da Espanha chorou.

E ninguém mais?

Frederico II ganhou a guerra dos Sete Anos? Quem mais ganhou?

Em cada página uma vitória. [...]

Em cada década um grande homem.

Quem pagava as despesas? Tantas histórias, Quantas perguntas. ${ }^{9}$

E assim se faz um educador, como se fazem as grandes construções, erguem-se os grandes monumentos, ajuntam-se e carregam-se as pedras para as grandes muralhas, projetam-se os grandes mosteiros, realizam-se as grandes conquistas e percorrem-se, em romarias, longos caminhos. A educação ética e estética do educador se faz com o outro - na construção de suas histórias, seus saberes, seus espantos, suas trocas, seus confrontos, seus olhares, seus gestos, seus (des)afetos, seus falares, seus silêncios, suas relações. Tanto melhores essas relações e mais cuidadas, tanto mais se firma a base para a feitura de si e de centenas de crianças e adolescentes que entregam a este sua educação. Sêneca, em 65 d.C., aconselhou seu amigo a "comunicar-se acima de tudo com pessoas que podiam torná-lo melhor ou que o levassem a realizar melhor as coisas". (PÖPPELMANN, 2010, p. 41). Quem sabe daí teria inspirado muitos pais, como inspirou os meus, a advertir sua prole: "Dize-me com quem andas e dir-te-ei quem és" Sabendo ou não ao certo a autoria da advertência, o certo é que o outro influencia imensamente na feitura do Eu, entre os quais encontra-se o Educador.

A feitura do educador, uma vez resultado do outro partícipe do conjunto de relações sociais, faz-se "outramente". É feita no plural e na pluralidade. "Cada um de nós é vários, é muitos, é uma prolixidade de si mesmos. [...] Na vasta colônia do nosso ser há gente de muitas espécies, pensando e sentindo diferentemente." (PESSOA, 2016, 390). E, nesse

\footnotetext{
${ }^{9}$ Bertold Brecht. In: Poemas, Campos das Letras, 1998

${ }^{10}$ Não se sabe ao certo se é um provérbio popular ou não, sabe-se, porém, que se aproxima de diferentes passagens do Livro Sagrado, quais sejam: "Quem anda com sábios será sábio, mas o companheiro dos insensatos será mau" (Provérbios 13:20). "Bem aventurado quem não anda no conselho dos ímpios [...], nem se assenta na roda dos escarnecedores" (Salmos 1:6). "Não vos enganeis: as más conversações corrompem os bons costumes" (Coríntios 15:33).
} 
momento em que a escritura se apodera de mim, o eu que escreve, que pensa e se mostra são muitos. Sou o que sente o corpo contente e os dedos que deslizam sobre o teclado. Não estou só. Minhas mãos já não são apenas duas. São alongamentos de muitos braços que abraçam comigo minhas causas e meus desafios. Minha voz se mistura com outras vozes que fazem comigo minhas considerações e mostra meus desejos, minhas faltas, agonias, minhas utopias. Revela meus sonhos, meu eu, quem sou. Vozes que me fazem na mistura de outras vozes de Coménio, Marx, Rousseau, Freire, Levinas, Sujomlinski, Schaff, meus poetas preferidos, meus alunos(as), e tantos outros tão importantes quanto estes.

E, se a feitura do educador é resultado do "conjunto das relações sociais" e se faz outramente, faz-se, com efeito, entre laços, ligas, desejos, éticas e estéticas. Laços que só se apertam "como responsabilidade". Na disposição de "dizer: eis-me aqui. Fazer alguma coisa por outrem. Dar. Ser espírito humano é isso." (LEVINAS, 2013, p. 81). Se faz de muitos e de diferentes bocadinhos de fragmentos humanos em convivência, em diálogo, em comunhão - com o outro, com o mundo - entre iguais e tão diversos de mim. A sociedade "é a presença do ser". O ser enquanto outro de si, é o eu mais a gente, uma feitura de nó(s). "Ora, é o outro que fala, ora é o outro-eu que se perde na confusão do eu-nós." (ECKER-HOFF, 2008, p. 134). O Eu, acrescenta a autora, sempre tem um pouco de "você" e em "você" tem um pouco do eu, misturando-se com as várias texturas do eu-você, nós-a gente que aí se encontram e se identificam (ECKER-HOFF, 2008). O eu, enquanto se faz humano, se torna. Educa-se. Educo-me. Os outros estão em mim. Fazendo-me. Completando-me. Dizendo o que não sei. Mostrando o que antes não via. "Eu tenho os outros em mim. Mesmo longe deles sou forçado ao seu convívio. Sozinho, multidões me cercam. Não tenho como fugir a não ser que fuja de mim." (PESSOA, 2016, p. 441). E, dessa mistura humana que se faz em relação aos tempos e aos espaços dos cursos de formação é preciso cuidar. Dessa relação, o professor está a depender para ser. Sua feitura não se faz com "blá, blá, blá" de um lado e o "ativismo do outro". (FREIRE, 2006). Nem se faz, insisto, aos encontrões - entre 
empurrões - mas em diálogo autêntico com o mundo e consigo mesmo, com o outro. Faz-se, não a partir de uma teoria aqui e uma prática acolá, mas do encontro (in)tenso entre ambas, na práxis. Não necessariamente para misturar, nem tampouco se conformar com a tímida mistura. Pois, “[...] Misturar prática e teoria é correr o risco de uma corromper a outra, pois nesta liga o bem estraga-se e o mal não se cura." ROUSSEAU apud FRANCO, 2015). É uma perturbação mútua, que ganha utilidade num movimento (in)tenso entre ambas gerando a práxis. Na práxis, "sujeito e realidade dialogam, se transformam e são por ela transformados". (FRANCO, 2015, p.134). Sua feitura, então, resguarda-se na ética e estética que dormita na práxis e "na compreensão dessa práxis" feita de fragmentos humanos.

A feitura do educador se faz enquanto pesquisa, lê, escreve e realiza o debate coletivo. É feita na teia de saberes, “em diálogo com suas circunstâncias". Faz-se nos encontros, nos congressos, nos seminários que promovem não apenas para "sair da regência", sair do "seu trabalho pesado" e, por vezes, "solitário", mas, para além de compartilhar seus queixumes, medos e espantos, trocar saberes e segredos humanos regados a entusiasmo e esperança. Nessas trocas, muitos contam suas histórias e outras histórias são tecidas, novos laços são enlaçado, novas redes enredadas. Educa-se, eleva-se a condição de ser. Faz-se o educador nas andanças pedagógicas, por onde entra em relação, se vive e se experimenta a condição de ser professor.

\section{A feitura do educador se faz na dialeticidade entre o aprender e o ensinar.}

“Aprendo para ensinar e ao ensinar, aprendo.” (Paulo Freire)

Não é de hoje que proclama-se a reciprocidade entre aprender e ensinar. Sêneca (4 a.C. - 65 d.C.) já advertira: "Docendo discimus" Ensinando, aprendemos. "Homines dum docent, discunt" equivale a dizer 
que "os homens enquanto ensinam aprendem". Este imperativo mostra também a dimensão antropológica básica, o que inclui a dimensão essencial da feitura docente, já que reúne um ser em constante aprender de si (NUNES \& ROMÃO, 2013). Numa de suas cartas, Sêneca escreveu ao amigo,

[...] não falava certamente de conhecimento, mas de formação de caráter. Deu especialmente a Lucílio o conselho de comunicar-se acima de tudo com pessoas que podiam torná-lo melhor ou que o levassem a realizar melhor as coisas. Com isso Sêneca não via nenhuma separação estrita entre professores e alunos, mas afirma que efeitos e benefícios são recíprocos. (PÖPPELMANN 2015, p. 41)

O educador se faz em reciprocidade. Os efeitos da ação de ensinar repercutem naquele que está a ensinar e naquele que está a aprender. Esta possibilidade, porém, nem sempre é fato. Ocorre que, por vezes, o professor ensina sem que o aluno aprenda, e, assim, sem despertar no aluno a consciência do que está docendo (ROMÃO et al, 2017). Estar aberto e consciente de sua natureza inconcluída, bem como do que está a aprender é fundamental. Assim, conscientes de que ignora-se muito mais do que sabe. (PINTO, 2005). Dispostos a ver para mudar, abertos para balanço e para inquietarem-se. Resta saber se aquele credenciado para educar está disposto a inquietar-se com o que lhe falta e, consciente, ingressar na busca de saberes mais pertinentes para educação de si. Para Rancière, o mestre é aquele que mantém o que busca em seu caminho, no qual está sozinho a procurar e o faz incessantemente (RANCIÈRE, 2007 p. 57). Para o autor o essencial é "essa contínua vigilância" que nunca se relaxa e tanto eleva aquele que sabe "tanto quanto o ignorante".

Isto posto, se é certo que sua feitura não se faz fora da busca, é certo, também, que nunca se finda. A educação do educador jamais ocorre com dia e hora marcados. Assim diz Paulo Freire: "ninguém começa a ser professor numa certa terça-feira às 4 horas da tarde [...]. Ninguém nasce professor ou está marcado para ser professor. A gente se forma como educador permanentemente na prática e na reflexão sobre a prática." (FREIRE, 1991, 
p. 58). Assim, é preciso muito mais para se fazer. Os espaços e tempos de formação têm importante papel na direção de criar condições objetivas de ação de modo a garantir não apenas uma formação de qualidade, mas condições de encontrar formas de atuação e afirmação no magistério. Importa desejar ser professor e encantar-se com a professoralidade e, portanto, com a elevação da existência humana.

\section{A dialética do desejo de docender e de encantar-se com a profissão de professor.}

A dialética do desejo aproxima-se de outras dialéticas imiscuídas nas andanças pela causa educativa - "a curiosidade", o "interesse sensível"11 a "amorosidade". Tal e qual o amor, assume uma função de "inspirar e nutrir a alma", pela compreensão e na direção do conhecimento profundo e da transformação de si (NUNES, 2017). Dá sentido à vida. O desejo carrega consigo o desassossego que o inquieta e o insere na busca. Na esteira do ideário freireano, sem o desejo que me move, que me inquieta, que me insere na busca, não aprendo, nem ensino, nem sigo em direção do horizonte que pretendo alcançar. Não é de hoje que a profissão de professor tem sido desdenhada pela sociedade, não apenas no contexto brasileiro. É sabido que Aurélio Agostinho, quando ainda não era reconhecido como santo, chegou em Roma quando ainda era uma província, no ano de 383, aos 28 anos de idade, e resolveu ser professor de retórica e poética. Então, narra Menguel que o renomado professor alugou uma casa, montou uma escola e reuniu vários jovens da província, mas "não demorou muito a perceber que não ganharia a vida como professor", (MENGUEL, 1997 p. 57), mesmo sendo reconhecido como um intelectual distinto. Seus alunos o escutavam em silêncio e atentos até o momento de acertar a remuneração das aulas e, logo em seguida sumiam.

\footnotetext{
11 "Para querer aquilo em relação ao qual a razão somente prescreve o dever ao ser racional afetado pela sensibilidade, é preciso de prazer ou de comprazimento no cumprimento do dever (...)" (KANT, apud HABERMAS, 2014, p.305)
} 
No Brasil, nunca o magistério esteve tão ameaçado e o professor tão desvalorizado. Nunca uma profissão foi tão admirada e tão depreciada a um só tempo. Nunca o professor foi agenda de tantos estranhamentos e até tido como causa ou motivo de um suposto "apagão"12. Nunca professores apareceram na mídia mais arrebatados pela dor que pelo riso. $\mathrm{O}$ "nãoprofessor" está em pauta e a negação docente está vinculada àquele para quem "o desejo de educar apagou-se".

Nesse cenário, o professor de "notável saber" é incluído na agenda da principal pasta de educação do país e o professor (licencia)do para ensinar é desdenhado. Tudo é feito para que seja apagado, e sem salário digno, sem gosto, sem chão, sem graça, e sem perspectivas, perca o desejo de professorar. Ademais, "pede-se-lhe quase tudo dá-se-lhe quase nada". Paciência, cadê? Um português, no ano de 1904, cansado com o descaso da profissão de professor e o rótulo de professores missionários ${ }^{13}$, ironizou:

[...] ser professor não é um sacerdócio: é um suicídio. É uma abdicação dos direitos mais rudimentares da existência. E, pelo visto, chega a espantar que o Estado misericordioso não pensasse ainda em exigir ao professor primário o voto de castidade perpétua, para que ele seja, em tudo, o monge moderno. Já o é na obediência, já o é na pobreza voluntária. (NÓVOA, 1998, p. 34)

O tempo em que a profissão docente foi tida como sacerdócio já morreu. Nem "sacerdócio", nem “dom”, nem laços de família ("tia”), nem “missão", nem "vocação"14, nem super-criatura condenada a uma capacidade extrema de suportar baixos salários, poucos saberes, pouco tempo para estudo e para preparação de suas aulas, sempre envoltas por más

\footnotetext{
12 "Haverá um apagão do professor no país. [...] O não-professor é aquele para quem o desejo de educar apagou-se. O desejo evadiu-se [...].” (DUNKER. In: Vida Simples, 2017)

13 Artigo difundido na revista Educação Nacional, n. 384, em 10. jan.1904. Apud Antonio Nóvoa (1998).

${ }^{14}$ Para Betti, “a representação da docência como 'vocação' e 'missão' de certa forma afastou socialmente a categoria dos professores da ideia de uma categoria profissional de trabalhadores que lutam por sua sobrevivência, prevalecendo a perspectiva de 'doação de si', o que determinou, e determina em muitos casos, as dificuldades que professores encontram em sua luta categorial por salários, dificuldades estas que estão presentes no âmbito social e político, bem como na cultura intracategoria”. (BETTI, 2009, p. 239).
} 
condições de trabalho. Parece, porém, que tudo se converge para a pobreza voluntária e até para que o voto não declarado de castidade se perpetue.

De acordo com os dados de uma pesquisa recente ${ }^{15}$ com alunos de Licencia(tura), cujos resultados são aqui mostrados, motivada pela curiosidade do suposto desejo e não desejo de ser professor, de acordo com o balanço das entrevistas, é comum uma mesma constatação: “[...] o professor é muito desvalorizado". Até o professor de "notório saber", em detrimento do professor licenciado para ensinar, foi inventado! Muito do que o movimento docente, no apelo de mobilização e de luta, sinaliza é que o desejo de docender não é estimulado e o professor tende a ser "apagado". Esquecem-se que em vez de apagar o professor seria saudável remunerá-lo com o valor da mesma moeda que se paga "ao magistrado". Pague-lhe o preço da moeda do valor e repercussão de seu papel. Pague-lhe pelo número de horas em que é professor. Pague-lhe com "o valor da moeda" de seu desejo de ensinar e encantar seus alunos com seus ensinamentos. Pague-lhe com o preço da moeda de seu encantamento com a causa educativa, de encantar novas infâncias, novos sujeitos de aprendizagens.

Nesse cenário, como cultivar a ética e estética do desejo de docender e encantar-se com a educação? O desejo "é uma experiência coletiva" que alimenta o presente e impulsiona para o futuro, ainda que indefinido e cheio de tensões. O desejo parece ser o traço mais carregado de fragmentos humanos, capaz de silenciar a discussão sobre a distinção entre o homem e o animal. Engels, depois de tratar de diversos argumentos polêmicos sobre esta distinção, conclui: "mas toda a ação dos animais, obedecendo a um plano, não conseguiu imprimir na Terra o selo de sua vontade. Somente o homem foi capaz de fazer isso". (ENGELS, 1991, p.223). E, a vontade enovelada com o desejo, guardada na memória e estimulada pela inteligência, impulsiona o educador para o desconhecido, para subir as montanhas e alcançar o horizonte. Não basta saber onde quer chegar,

\footnotetext{
${ }^{15}$ A pesquisa foi realidade enquanto professora de Didática e teve como mote uma das questões aqui lançadas com alunos de licenciatura - De onde vem o desejo de ser professor? - As respostas foram coletadas com alunos de 7 licenciatura oferecidas, 4 deles licenciando-se em Pedagogia.
} 
importa ter "motivos e boas razões" para se impulsionar a caminhar em direção ao horizonte. É preciso querer. Querer, no entanto, não é poder. O poeta português explica que "quem pôde, quis antes de poder só depois de poder. Quem quer nunca há de poder, porque se perde em querer". (PESSOA, 2016, p. 361). Se perde em muitos quereres. Querer é aninhar a vontade para parir o desejo e, assim, entrar em ação. E, é a vontade "que transforma o desejo em uma intenção, em um projeto, em uma determinação de agir". (ARENDT, 1984, p. 95). A vontade - "órgão mental" que move a ação - acrescenta, lança o homem para o futuro, para iniciar algo novo ora elegendo alternativas, ora colocando as ações em marcha (ARENDT, 1984). Em todo desejo de educar e encantar-se com a profissão docente avulta o desejo de transformação social e, simultaneamente, o desejo que se projeta "de melhorar os indivíduos" e elevar seus horizontes. Nessa teia de desejos “aparece o apelo à educação, uma esperança que é também um estímulo para a responsabilidade" (SACRISTÁN, 1999, p. 36) e ao encantamento pela causa educativa. Emerge um estímulo à educação do educador e ao desejo de docender. Indaga-se, então: O que leva alguém a desejar ser professor, se afirmar na profissão e encantar-se com o magistério? Na ação de docender dormita o desejo de ser professor? Muitas vezes a decisão pelo magistério vem sem desejo e, assim, a professoralidade já não será um trabalho digno, mas uma ocupação opaca, similar a uma atividade qualquer - sem continuidade, sem objetividade, sem seguir além de onde está.

Isso posto, sinalizo a dialética do desejo de ser professor, bem como o começo de tudo, digo, em que este desejo se projeta e se eleva. O desejo de ser professor não ocorre suavemente, nem de maneira unilateral. Acontece dialeticamente - entre o querer e o não querer, entre o ser e o deixar de ser professor, entre a permanência e o abandono, entre a desilusão e admiração, entre o medo e a aventura. Nada é tão mais apropriado à educação, e ao professor que por ela responde, do que aventurar-se. Disso, alimentam-se as tensões da docência e do desejo de docender ${ }^{16}$ imiscuídas

\footnotetext{
${ }^{16}$ Utilizei-me do verbo docender por três razões principais, a saber: é mais próximo da docência na sua origem docere, o que supõe a reciprocidade entre aquele que ensina e aquele que aprende. Ambos são afetados pela construção da docência. Nela, insere-se
} 
entre as lembranças que oscilam entre a dor e o riso, a crença e a descrença, a hostilização e a exaltação, a depreciação e a valorização, a desesperança e a esperança, o desencanto e o encantamento pela profissão de professor. Essas tensões em que, por vezes, sobressai o sentimento de desencanto, ultrapassam os muros do território brasileiro. José Esteve, professor da Universidade de Málaga, ficou famoso por pesquisar o mal-estar docente e mostrar as causas do não desejo e da ação de desiludir-se com a profissão docente. Diz o autor,

\begin{abstract}
Este mesmo sentimento de desencanto afecta (sic) hoje muitos professores, quando comparam a situação do ensino há alguns anos atrás com a realidade quotidiana das escolas em que trabalham. O sentimento de insegurança está na origem do cepticismo (sic) e da recusa dos professores em relação às novas políticas de reforma educativa. [...] A sociedade parece que deixou de acreditar na educação como promessa de um futuro melhor, os professores enfrentam a sua profissão com uma atitude de desilusão e de renúncia, que se foi desenvolvendo em paralelo com a degradação da sua imagem social. (ESTEVE, 1996, p. 95-96)
\end{abstract}

Alguns alunos entrevistados nos cursos de licenciatura, sujeitos de estudo recente/2016, revelam motivos similares do não-desejo pelo ofício de ser professor, quais sejam: a descrença na educação, a insegurança gerada por decisões apressadas dos órgãos políticos, a desvalorização, a má remuneração, a frustração, a falta de opção, a economia relativa aos cursos de licenciatura, - a falta de disposição em aventurar-se. Muitos fazem o curso, ainda inseguros com a escolha e até pensando noutras saídas de formação longe da docência. Diversas narrativas de diferentes autorias do aluno de licenciatura se aproximam:

A1 - "Os motivos para não desejar ser professor são muitos".

necessariamente a discência - "Docendo, discimus" e isso ocorre a dois, digo, mais de um. Aventuro-me a afirmar que ao ensinar nem sempre o professor entra em reciprocidade com o aluno, mas ao docender seus alunos discunt, e, portanto, aprendem. Criam, conforme descrito no corpo do texto, laços, ligas, liga(ações) em reciprocidade, em responsabilidade de um sobre o outro e outro sobre um. É uma ação que no tempo aqui conjugado propõe uma nova confirguração didática, que só é possível diante da disposição e do consentimento ativo daquele que está a docender e aquele que está discunt. Tem como imperativo fazer valer o espírito, a condição e elevação do ser humano. 
A2 - "Não tenho vontade de ser professor devido às dificuldades no ramo educativo, interferências políticas que não estimulam, a falta de reconhecimento."

A3 - "Não tenho vontade de ser professor...existem muitos motivos... a desvalorização da classe e a má remuneração são os principais."

A4 - "Não tenho desejo de ser professora, porque quero ser médica."

Outras narrativas mostram pouca clareza em relação ao curso e, assim, sobre a escolha feita. Uma aluna reconhece que narrar sobre o desejo de ser professor "não é fácil, embora fazendo licenciatura". E acrescenta:

\begin{abstract}
No momento tenho o desejo de ensinar ciências. Não sei direito por quê. Tenho curiosidade de ensinar as partes da planta, suas funções. Meu pensamento está confuso. Mas também não me vejo fazendo outro curso. Tenho medo de não ser uma boa professora. As razões não estão tão claras, vou pensar mais sobre isso. (Aluna licenciatura)

No meu caso não pretendo lecionar. Estudo Pedagogia por falta de opção no Campus e não tenho condições de estudar em outra cidade com o nível superior. Não me vejo professora. (Aluna Pedagogia)
\end{abstract}

Se ocupar as cadeiras dos cursos de Licencia(tura) sem desejo e sem a consciência clara das razões de estar ali assusta; o susto aumenta, ainda mais, quando este aluno é do curso de Pedagogia. O desejo de ser professor também dormita no desejo de se ver professor na experiência de sua função. E, as razões do não-desejo de ser professor "são muitas", as razões que fazem brotar o desejo de ser são maiores e muito mais que muitos. Os motivos, de fato, são explícitos, similares, e, por vezes, óbvios e esdrúxulos. Até a busca desesperada por uma ocupação que julga fácil é relacionada. Aí já não precisa mais de desejo, nem formação - ao menos de qualidade. O começo de tudo nasce de vários e distintos motes - ora efêmeros, ora duradouros, ora de fragmentos pueris - ora de fundamentos narrados por exalunos de Licencia(tura) em Pedagogia ${ }^{17}$, muitos dos quais amparados na

\footnotetext{
17 Durante dois semestres, pesquisei, junto com os alunos de licenciatura - em particular Pedagogia -, sobre o desejo de ser professor. Percebi que muitas das razões se amparam na superficialidade ou em motivos sem qualquer fundamento. Por isso, classifiquei as narrativas como fragmentos do desejo de ser professor.
} 
superficialidade, embora nenhum deles deva ser desconsiderado, quais sejam:

\author{
gostar de criança - "amo crianças"; \\ gostar de gente - "gosto de estar com as pessoas"; \\ admiração pela profissão - "quero ser professora porque \\ é uma profissão muito bonita". \\ "filho de peixe, peixinho é" - "Já comia no prato que \\ ela me alimentou. Foi pela profissão que minha mãe me \\ passou o bastão. Não foi por acaso que a educação a \\ mim chegou. Não foi eu quem a escolheu, ela que me \\ abraçou." (Aluno de Pedagogia)
}

São a partir dos exemplos de professores marcantes, todavia, que as narrativas mostram convicção do desejo de docender.

\begin{abstract}
Surgiu quando ainda era criança. Admirava muito meu professor de educação física que dava aula não por obrigação, mas porque gostava do que estava fazendo. Ele usava várias metodologias $[\ldots]$ brincadeiras, histórias - criadas por ele mesmo - que nos ajudavam a visualizar o que estava sendo exposto por ele. Além do que, por mais que eu não tivesse noção do que, de fato, girava em torno dessa profissão, eu o admirava. E à medida que eu ia avançando de uma série para outra, me convencia cada vez mais de que essa era a profissão que eu queria e quero seguir. (Graduando de licenciatura específica)
\end{abstract}

Outra depoente segue, na mesma linha, resumindo vários bons motivos para seguir na profissão, numa visão mais abrangente:

\begin{abstract}
Professor é a profissão mais linda e importante do mundo [...]. Tal ofício exerce sobre todas as outras profissões. É a profissão que abre as portas para todas as outras profissões. Porém, a tarefa é árdua e difícil problemas de violência, indisciplina e más condições físicas e estruturais das escolas. Mas, pretendo ingressar nesse caminho por achar que posso ajudar a mudar um pouco a realidade, apesar do baixo salário e da desvalorização dessa profissão pelos gestores públicos. (Graduanda em Pedagogia)
\end{abstract}

Outra narrativa mostra que o desejo de ser docente é um processo que vem de longa data - "Sonho de criança" - "Meu desejo de ser professor não veio de uma hora para outra, veio desde quando era criança.” Outra fala mostra que seu desejo se alimenta do gosto de "abrir os olhos das crianças para coisas que estavam ao seu redor, mas que antes não percebiam”. (aluna 
da Pedagogia). Outros relatos dão conta que o status perdido do professor não morreu: "Quero ser professora, o que para mim será um grande privilégio." Outras, ainda, estão longe de entender a dimensão e relevância da profisssão em pauta: "Meu desejo de ser professora é para gozar as férias duas vezes por ano.” Logo no primeiro ano, esta aluna iria constatar que ninguém, mediante o grau de exigência, suportaria a docência sem que durante o ano letivo o direito às férias na metade do "caminho caminhado" fosse assegurado. Este hiato pedagógico contribui não apenas para o descanso do professor, mas para a confirmação do desejo de se afirmar na profissão e para melhorar sua prática.

Toda discussão em que a educação do educador está em pauta tem como mote principal a melhoria da prática. Uma questão se (im)põe: Quais seriam as tarefas das Escolas de Formação de Professores para encantar novos docentes para novas infâncias e novos sujeitos de aprendizagem? A questão é abrangente, mas caminhando para finalização do presente artigo, irei apenas pinçar algumas delas, que se engendram e se complementam de modo que não caiam no esquecimento.

\section{- Criar momentos sagrados de leitura com estudo.}

"Não se mede o estudo pelo número de páginas lidas numa noite ou pela quantidade de livros lidos num semestre. Estudar não é um ato de consumir ideias, mas de criá-las e recriá-las." (Paulo Freire)

Há de se experimentar o prazer com o estudo. Há de se desenvolver o hábito de ler. Leitura nas suas várias frentes - de mundo, da palavra, de si e do outro, de modo a relacionar os saberes sabidos a outras leituras, outros mundos, outras histórias. Importa, “[...] não apenas o ato de ler o mundo, o livro, o espaço, a natureza, a vida, mas de ler-nos e entender-nos nesse mundo na história". (ARROYO, 2004, p. 234). Quantas maneiras de viver a experiência da leitura. Que registros de leitura de papel e do agir humano são feitas em cada dia? Quais seus efeitos na educação do educador e de seus alunos? Que registros? Não há formação alguma protegida da neutralidade, fora de influências e interferências da leitura do humano, da 
leitura impressa, da leitura online, da leitura do mundo. Fala-se tanto da leitura do mundo enovelada com a leitura da palavra, mas como enovelar uma sem a existência assumida ou sem eliminar o descaso para com a outra? Fala-se tanto da importância da leitura com estudo na formação, mas muitos saem do curso de formação de professor sem que tenham sido persuadidos e encantados com o prazer de ler e de estudar. Sem que tenham internalizado a necessidade do estudo em suas práticas educativas, em suas vidas. Não é de bom senso, nem de bom trato, nem de bom grado a quem estuda, "alienar-se do texto, renunciando assim a atitude em face dele". (FREIRE, 2001, p.11). O autor, ainda, acrescenta: “A atitude crítica no estudo é a mesma que deve ser tomada diante do mundo, da realidade, da existência. Uma atitude de adentramento com a qual se vá alcançando a razão de ser dos fatos cada vez mais lucidamente.” (FREIRE, 2001, p. 11). É no movimento de idas e vindas, no barulho do folhear das páginas, dos sussurros do leitor com o livro/texto, discernindo o útil do inútil, dialogando e até discordando, que se alumia o olhar daquele que lê para o que antes não via; que provoca este leitor para inquietar-se com as ações que imprime na sua práxis; que ultrapassa a superficialidade e o senso comum de seus fazeres.

\section{- Ir além da formação cesta básica.}

Em diferentes encontros, congressos, seminários em que a educação ocupa o centro do palco, a formação do professor ganha notoriedade, a pretexto das sucessivas críticas e das acusações comuns, em face das fragilidades e das faltas relacionadas aos cursos de formação referentes à imagem do professor. Sem tempo para estudo, sem salários dignos, sem chance de refletir e trocar seus queixumes, erros e acertos, sem eira nem beira, não são poucos os professores que sobrevivem sem sair do mínimo e sem acrescentar nada ou quase nada ao que já adquiriu até o dia em que recebera o diploma. A conformidade, entre poucos inconformados, é explícita. Nenhuma mudança funciona sem que a inconformidade de ficar 
com o mínimo seja combatida, sem que "os grandes e muitos" internalizem o alcance da educação e dos profissionais que por ela respondem. Se é certo que a formação requer cuidados, é certo, igualmente, que estes cuidados não se encerram na formação. Todo curso de formação de professor, mesmo aqueles com uma carga horária razoável, sempre deixará muitos bons estudos por se fazer, outras leituras por se findar, outras discussões por se concluir. Aprender a ler, a estudar, a escrever e até se valer da retórica são capacidades que vão além dos cursos de formação. É imperativo, porém, que a formação assegure a base para fazer andar, e andar com direção e na direção de estabelecer e afirmar o diálogo autêntico com a escola básica. $\mathrm{Na}$ atualidade, a distância entre a universidade e escola básica tem sido cada vez mais refutada, embora efetivamente pouco se tem alcançado. A falta deste alcance é o reflexo da precarização da profissão e da valorização do professor, e a denúncia das fragilidades das políticas de formação. Orso (2011), entre outros, mostra que se observar o entorno, percebe-se que os investimentos, em particular, nos cursos de Licenciatura, são precários; as escolas estão em péssimas condições de trabalho - classes superlotadas, com o mínimo de material, mínimo de estrutura - bibliotecas sem livros, salas de informática sem computadores. Internet? Serviço de luxo. A história da educação, resume Saviani (2010), mostra que o caminho perscrutado pelo educador tem sido marcado "desde suas origens, pela desvalorização social de sua profissão, acompanhada, ao mesmo tempo, pela exigência, por parte da sociedade, de que ele exerça a sua atividade com extrema dedicação". (SAVIANI, 2010, 134). O autor, ainda, diz mais:

[...] a vida do professor sintetiza dois sentidos contraditórios encerrados na palavra paixão [...]. Com efeito, paixão significa envolvimento afetivo, amor profundo, entusiasmo muito vivo, dedicação extremada a uma causa, compromisso radical carregado de afetividade. Mas significa também padecimento e sofrimento. Ora, ser professor hoje em dia envolve esses dois significados, e parece mesmo que a própria política governamental manifesta esse entendimento ao cobrar dos professores extrema dedicação e responsabizandoos pelo fracasso escolar e, ao mesmo tempo, submetendo-os a condições precárias de trabalhos com salários aviltantes. Importa que os professores estejam 
conscientes dessa situação contraditória e se disponham a organizar-se e lutar para mudar este estado de coisas. (SAVIANI, 2010, p.134)

Importa incluir na luta por uma outra formação, ações que façam valer a aproximação da formação e a escola básica. A realização do estágio supervisionado pode ser um bom começo, senão uma ação, entre tantas, para debutar na docência e despontar o desejo de docender.

- Valer-se dos estágios supervisionados para criar ocasiões efetivas de “debutar na profissão” e se afirmar no magistério.

A feitura do educador para a escola básica precisa considerar "seu campo de prática" e relacionar a este universo "os conhecimentos necessários", em particular, para educar novas infâncias e adolescências. A escolha de uma escola para experienciar o estágio supervisionado obrigatório interfere, e muito, na qualidade da formação. Se aquilo que o aluno pode ver e viver no interior da escola lhe trouxe desencantos e espantos motivados por uma pedagogia às avessas, só pode interferir e influir negativamente na sua formação, no desejo de ser professor e de exercer a docência e encantar-se com a profissão.

A realização dos estágios supervisionados obrigatórios quase sempre são motivos de duras críticas e acusações. Para Gatti,

\footnotetext{
os estágios mostram-se fragilizados, constam nas propostas curriculares sem planejamento e sem vinculação clara com os sistemas escolares, sem explicitar as formas de sua supervisão. Some-se a isso a constatação de que esses cursos [...] são feitos em grande parte à base de apostilas, resumos e cópias de trechos ou capítulos de livros, ficando evidente certo grau de precariedade nos conhecimentos oferecidos. (GATTI, 2009, p. 258)
}

Isso mostra grandes ocasiões perdidas, uma grande perda no aproveitamento da articulação refletida e útil à teoria e à prática e, mais que isso, à compreensão da práxis. É imperativo que a promoção da práxis seja entendida e experimentada. A educação do educador há de contemplar, no caminho perscrutado de formação, a capacidade de interferir na escola 
básica, a partir da utilidade da teoria na prática e viver, assim, a práxis educativa em suas possibilidades em favor da evolução da humanidade.

\section{- Eleger saberes e realizar ações "com compromisso social e político".}

A educação do educador implica também, e sobretudo, formá-los como profissionais capazes de produzir saberes e ações, conscientes de seu papel social e político. Não dá para educar o educador "como objetos dotados de habilidades e de competências instaladas sob forma de fazeres que nada significam na prática [...] e pouco acrescentam para que tenha um bom começo". (FRANCO, 2008 p. 134). De acordo com a autora, muitos saem da faculdade "sem saber como organizar um bom começo". Seus voos são rasteiros, embora, por vezes, sonhem em voar alto. Suas dúvidas são sempre maiores que suas possíveis certezas ou necessárias convicções. Não cabe, todavia, a um correto e bem planejado curso de educação do educador sanar todas as indagações e eliminar todos os espantos. Que graça teria pensar em formas de ação "quando tudo está definido"? Ensinar quando os alunos já sabem e sequer precisam de sua ajuda? Ademais, nunca será possível evitar situações para as quais o professor não foi preparado e, antecipadamente, preparar-se para lidar com tais situações. Se antecipa e se vê até as situações difíceis de prever.

Em educação haverá sempre situações inusitadas a enfrentar, muitas das quais e para as quais o pedagogo não foi, nem está, preparado. Muito do que ocorre nos espaços e nos tempos de formação restringem e até elimininam as possibilidades do gosto, do desejo de docender e de ascender na profissão de educador - destaca-se a ênfase nas normatizações, nos saberes disciplinares e disciplinados, na obediência às ações curriculares aprisionadas em grades. Acrescente-se que "o enquadramento disciplinar e normativo afoga o sonho". (ARROYO 2000, p. 149), e engessa o desejo de docender. $\mathrm{O}$ descuidar das relações humanas emperram os motivos para encantar-se com a profisssão. Afeta, em maior ou menor escala, até o gosto de "saborear a sabedoria". Determinar-se na tarefa de construir uma outra educação do educador e educar novas infâncias que não se findam na 
primeira etapa de educação. Isto supõe “driblar esses controles do próprio prazer de educar e educar-se. Quando tudo está definido, que graça tem ser pedagogo? Como conduzir a infância por novos caminhos se as normas nos acorrentam?" (ARROYO, 2000, p. 148); e se a licença para seguir com desejo e encantar-se com o magistério são banalizados?

\section{A conclusão em feitio}

O desejo de docender nasce da mesma raiz que projeta a educação e a esperança à disposição em lidar com o não terminado. E, com efeito, entrar na busca incessante pelo que não se finda e, assim, jamais chega ao ponto final. Talvez, por isso, concluir seja uma tarefa tão exigente. Para Fernando Pessoa é inevitável no momento da conclusão livrar-se do cansaço, porque quanto mais se pensa, mais se analisa, mais se distingue, mais se tem que dizer e, assim, menos se chega a uma conclusão (PESSOA, 2016). Uma boa conclusão, e tanto mais instigante, não se encerra com pontos finais, mas se finda interrompida, com pontos e vírgulas. Há tanto por se dizer, por se concluir depois do dito.

À guisa da conclusão, afirmo que a presente reflexão, cujo mote foi a Educação do Educador, gira em torno do pensar sobre a ética e a estética do desejo de docender e de encantar-se com a docência. Impossível, todavia, apresentar esta reflexão à margem de um contexto às avessas da opção e afirmação pelo/no magistério. Esta realidade, mesmo (temer)osa, não enclausura o professor, nem aprisiona seu desejo de ser e de seguir como educador. Outras influências e interferências engendram esse desejar. O desejo de ser professor nasce com o mesmo desejo de ser criança na infância. Para Sujomlinski (1975), na infância cada criança é um poeta. E, acrescenta o poeta, desperta o sentimento humano da beleza. O desejo de docender nasce com o desejo de ver o sol, isto é, de acordo com o entendimento que a criança tem:

\footnotetext{
O sol é a fonte de vida.

E sem ele a terra não seria a mesma coisa.

Sem ele a gente não teria luz, nem esperança.

Sem ele a gente seria nada, bichos da noite.

Não fazia sentido acordar de dia ou de noite.

Ter o prazer de acordar.

Por que a gente acorda para ver o sol

E viver a vida. (Thales, 11 anos, $6^{\circ}$ ano)
} 
O desejo de docender, como a vida, pede para se renovar todos os dias. Thales, meu filho único, mostra a mim e ao professor de geografia, que pediu uma redação sobre o sol, que sem o desejo, assim como sem o sol, a gente seria "bichos da noite". Sem o sol, assim como sem o desejo, os dias seriam iguais, não teria sentido acordar de dia ou de noite. E não basta acordar, é necessário acordar com o desejo de seguir, de sentir, de sonhar, de docender, de amar, de admirar, de "esperançar" e "viver a vida" e dizer: Eis-me aqui. $\mathrm{O}$ desejo há de nascer junto com o nascer do sol. E adormecer com a poética infantil. A criação poética infantil é um acontecimento tão natural como é natural para criança o desenho. "Todos os niños dibujan”. A criação poética, todavia, se torna fenômeno corrente na vida das crianças quando o educador revela, diante delas, a beleza do entorno e a beleza da palavra (SUJOMLINSKI, 1975).

A educação do educador se faz outramente, sem ficar à margem da ética e da estética do desejo de professorar. Mas é o lugar em que este ofício o coloca que impulsiona o seu desejo de ser e docender. Desejo de exercer a docência e de encantar-se com a profissão faz morada nas práticas "humanizadeiras", nas relações justas, enquanto autora e coautora da feitura de mim, na feitura inteira da humanidade. Seu germe está na educação e, onde ela se dá, se faz e cria raízes. Este lugar será tão melhor e mais acolhedor quando cada qual estiver disposto a "aprender com todos" sem que seja aos empurrões e aos encontrões . O meu desejo faz morada na "artesania" pela humanização de novas infâncias. Esta artesania humana oscila da esperança à desilusão, mas será sempre maior que a força das pedras atiradas no meu entusiasmo e lançadas sobre minha esperança.

O encantamento com a educação e o desejo de docender dormita na ética e na estética humana que se expressa antes de tudo "no respeito a dignidade humana". Se dá e evolui entre os diversos e tão iguais a mim que lutam para fazer prevalecer a humanização na sociedade maquínica. O desejo de ser professor e de encantar-se com a profissão em tempos sombrios, frios e temerosos, ultrapassa os limites da quadradura da aula. 
Quero ser professor porque é encantatório ver o aluno seguir. E, abrir seus olhos para coisas mais simples, do seu entorno, de seu viver, mas que antes não via. Nada se compara à alegria de o aluno ter superado suas dificuldades, muitas das quais decorrentes de mim. A feitura do educador, de mim e de si, assim como a experiência do desejo pela docência e em docender, se faz na dialeticidade e na dialogia inerente à relação educativa. E, em relação me faço, sou. O outro me salva. E esta condição que o outro possibilita-me há de prevalecer. $\mathrm{O}$ outro tanto mais educado, tanto mais possibilidades de "salvação". Quando as condições de ser permitirem sentir o outro na sua plenitude, estarei salva (LISPECTOR, 1999). O outro desenha os traços de meu rosto e traz, no seu retrato, traços de mim. Revela quem sou enquanto me faz (BRANDÃO, 2005). Com ele elevo minha condição de ser e até do desejo de docender - entrar em relação, em reciprocidade com responsabilidade. Este desejo reside, enfim, nas (im)possibilidades regadas entre risos, laços, ligas, liga(ação) - essência da docência. Em liga(ação) há de se descobrir a dimensão do estar ligado a alguém. Estar ligado é “estar junto", para além do ajuntar-se por meio dos fios. É chegar ao outro e atravessar suas retinas. Meu querer querido pelo magistério permite-me aprender olhando nos olhos de quem vê e me vê. Olhos que "têm raízes pelo corpo inteiro". Vir a ser educador se faz "no movimento recíproco dos olhos de quem ensina para os olhos de quem aprende". (SÁ, 2014, p. 151). A falta disso revela a falta do desejo que nunca vem no singular.

O educador "é patrimônio da humanidade". É preciso prepará-lo e despertar nele a ética e estética do desejo de docender, de reinventar a escola, de "acarinhar o conhecimento" e encantar-se com a profissão. Não é uma construção fácil, para qualquer um ao acaso e, muito menos, uma tarefa apressada, que se materialize no curto espaço de tempo, menos, ainda, no isolamento. Não é uma tarefa simples, uma vez que nunca se finda e não tem como se fazer fora das tensões imiscuídas na "humana docência" e, mais que isso, livre das influências e interferências da sociedade. O problema, porém, não está nas tensões, mas na fuga em lidar com elas e 
lograr remover de forma airosa as amarras impostas pela política às avessas de formação de professor. Não são poucas as pedras do caminho. E, entre pedras e pedregrulho, o desejo de docender há de fazer valer a prevalência da humanização na sociedade em que tanto sobrevela a tecnologia, enaltece a relação homem e máquina, esquecendo as relações humanas. Como adverte a sabedoria da poetisa Clarice Lispector:

O homem foi programado por Deus para resolver problemas. Mas começou a criá-los em vez de resolvêlos. A máquina foi programada pelo homem para resolver problemas que ele criou. Mas ela, a máquina, está começando também a criar problemas que desorientaam e engolem o homem. A máquina continua crescendo. Está enorme. A ponto de que talvez o homem deixe de se ruma organização humana... Deus criou um problema para si proprio. Ele terminará destruindo a máquina e recomeçando pela ignorância do homem diante da maça. Ou o homem será um triste antepassado da máquina; melhor o mistério do paraíso.

\section{Referências} (LISPECTOR, 1999, p. 275)

ARENDT, Hanna. La vida del espiritu. Madrid: Centro de estudos constitucionales. 1984.

ARROYO, Miguel. Ofício do Mestre: imagens e auto-imagens. RJ:

Petrópolis Vozes, 2000.

ARROYO, Miguel. Imagens quebradas: trajetórias e tempos de alunos e mestres. Petrópolis, RJ: Vozes, 2004.

ARISTÓTELES. Ética a Nicômaco. São Paulo: Matim Claret, 2011.

BAUMAN, Zigmunt. Modernidade Líquida. Rio de Janeiro: Jorge Zahar, 2001.

BETTT, Bernadete Angelina. A formação continuada no Brasil. In: GATTI, Bernadete e BARRETO, Elba. Professores do Brasil: impasses e desafios. Brasilia: UNESCO, 2009. 
BRECHT, Bertold. Poemas. In Campo das Letras, 1998.

ECO, Umberto. Alguns mortos a menos. In: O Estado de São Paulo, Editorial 10/8, 2003.

ECKERT-HOFF, Beatriz. Escritura de si e identidade: o sujeito-professor em formação. Campinas, São Paulo: Mercado das Letras, 2008.

ENGELS, Friedrich. Humanização do Macaco pelo Trabalho. In: A Dialética na Natureza. Rio de Janeiro: Paz e Terra, 1979.

ESTEVE, José. Mudanças sociais e função docente. In: NOVOA, Antonio et. al. (org.). Profissão Professor. Portugal: Porto Editora, 1991.

FRANCO, Amalia. Pedagogia como ciência da educação. São Paulo: Cortês, 2008.

FREIRE, Paulo. Educação na Cidade. São Paulo: Cortêz, 1991.

FREIRE, Paulo. Considerações sobre o ato de estudar. In: Ação Cultural para Liberdade e outros escritos. São Paulo: Paz e Terra, 2001.

FREIRE, Paulo. Pedagogia da autonomia. São Paulo: Paz e Terra, 2006.

HABERMANS, Jürgen. Conhecimento e interesse. São Paulo: UNESP, 2014.

LISPECTOR, Clarice. A descoberta do mundo. Rio de Janeiro: Rocco, 1999.

LEVINAS, Emmanuel. Ética e Infinito. Lisboa, Portugal: Edições 70, 2013. 
LEVINAS, Emmanuel. Totalidade e infinito. Coimbra: Edições 70, Lda, 2014.

MANGUEL, Alberto. Os leitores silenciosos. In: Uma história da leitura. São Paulo: Companhia das Letras, 1997.

MARX, Karl e ENGELS, Friedrich. A Ideologia Alemã. Martins Fontes. S. Paulo: 1998.

MARX, Karl e ENGELS, Friedrich. Educação, Formação e Trabalho. Textos sobre Educação e Ensino. São Paulo: Centauro, 2004.

NÓVOA, Antonio. Relação Escola - Sociedade: Novas respostas para um velho problema. In: SERBINO, Raquel et. al. (org.). Formação de Professores. UNESP, 1998.

NUNES, Cesar e ROMÃO, Sampaio Eliana. Educação Brasileira, as novas diretrizes curriculares e a formação de professores. In: Educação, Docência e Memória: Desa(fios) para formação de professores. Campinas, SP: LIBRUM, 2013.

NUNES, Cesar. Platão e Dialética: entre a Filosofia do Amor e o Amor à Filosofia. Campinas: Lebrum \& Brasílica, 2017.

ORSO, Paulino José. O desafio da formação do educador na perspectiva do marxismo. Revista HISTEDBR On-line, Campinas, número especial p. 5873, abr. 2011.

PESSOA, Fernando. Desassossego. São Paulo: Companhia das Letras, 2016.

PINTO, Álvaro Vieira. Sete Lições sobre Educação de Adultos. São Paulo: Cortez, 2005. 
PÖPPELMANN, Christa. Dicionário de máximas e expressões em latim. São Paulo: Editora Escala, 2015.

RANCIÈRE, Jacques. O mestre ignorante: cinco lições sobre a emancipação intelectual. Belo Horizonte: Autêntica. 2007.

ROMÃO, Sampaio Eliana. A docência entre guardados, perdidos e achados: narrativas e memória. In: Educação, Docência e Memória. Maceió: EDUFAL, 2013.

ROMÃO, Sampaio Eliana. Conviver em rede e aprender enredado: desafios para Didática on-line. In: Didática on-line: teorias e práticas. Vol. I. Maceió: EDUFAL, 2017.

ROMANO, Vicente. A formação da mentalidade submissa. Portugal: Deriva Editores, 2006.

ROSA, Guimarães. Grandes Sertão Veredas. Rio de Janeiro: Nova Fronteira, 2001.

SÁ, Eduardo. Hoje não vou à escola! Porque é que os bons alunos não tiram sempre boas notas? Córdova. Portugal: Lua de Papel, 2015.

SAVIANI, Dermeval. Sobre a natureza e especifidade da educação. In: Pedagogia Histórico-Crítica. Campinas: Autores Associados, 2003.

SAVIANI, Dermeval. Educação, Mudança, Contestação. Interlocuções pedagógicas. Educação, Mudança, Contestação. Campinas, SP: Autores Associados, 2010, p. 150- 173.

SACRISTAN, Gimeno. O que move a ação educativa? A racionalidade possível na pós-modernidade e a relação teoria-prática. In: Poderes Instáveis em educação. Porto Alegre: ArtMed, 1999. 
SUCHODOLSKI, Bogdan. A Pedagogia e as grandes correntes filosóficas - a pedagogia da Essência e a Pedagogia da Existência. São Paulo: Centauro Editora, 2002.

SUJOMLINSKI, Vasili. Pensamiento pedagógico. Moscú: Progreso, 1975.

SCHAFF, Adam. A sociedade informática. São Paulo: Editora Brasiliense, 1995.

TRINDADE, Rui. Ação educativa como um empreendimento ético: uma reflexão que se quer mais urgente do que apressada. GARCIA, Joe \& Trindade, Rui (org.) In: Ética e Educação: questões e reflexões. Rio de Janeiro:WAK, 2012. 